\title{
Premarital sexual practice and associated factors among adolescents in the refugee camps in Tigray, northern Ethiopia
}

\author{
Hailay Gebreyesus ${ }^{1 *}$, Tesfay Berhe' ${ }^{1}$ Zemichael Welegebriel ${ }^{1}$, Tewolde Wubayehu², Gebretsadik Hailemariam4, \\ Gebretsadkan Gebrekirstos $^{3}$ and Mebrahtu Teweldemedhin ${ }^{3}$
}

\begin{abstract}
Objective: Premarital sexual practice during adolescence time may lead to different sexual and reproductive health problems including HIV/AIDS. This study was aimed to assess the prevalence of premarital sexual practice and associated factors among adolescents living in the refugee camps in Tigray, northern Ethiopia.

Result: The prevalence of premarital sexual practice was $47.6 \%$ [95\% Cl $(43.3 \%, 51.9 \%)]$. The age (mean \pm SD) of the study participants was $17.4 \pm 2.71$ (15-24 years) and $68.8 \%$ of them were males. Being in the age group 14-19 years $[A O R=4.50,95 \% \mathrm{Cl}(2.29-8.84)]$ or $20-24$ years $[A O R=9.76, \mathrm{Cl}(4.58-20.82)]$, living with friends $[A O R=5.24,95 \% \mathrm{Cl}$ $(2.28-12.05)]$ or alone $[\mathrm{AOR}=5.72,95 \% \mathrm{Cl}(2.69-12.19)]$, being in primary school $[\mathrm{AOR}=6.93,95 \% \mathrm{Cl}(3.08-15.57)]$ or college $[A O R=4.33, \mathrm{Cl}(1.44-13.02)]$, getting pocket money $[\mathrm{AOR}=4.14,95 \% \mathrm{Cl}(2.31-7.41)]$, parents being either divorced $[A O R=5.11,95 \% \mathrm{Cl}(2.42-10.80)]$ or widowed [AOR $=3.52,95 \% \mathrm{Cl}(1.69-7.33)]$, alcohol consumption $[A O R=1.99,95 \% \mathrm{Cl}(1.20-3.38)]$ were independent predictors of premarital sexual practice among the adolescents.
\end{abstract}

Keywords: Premarital sexual practice, Health risks, Refugee adolescent, Tigray, Ethiopia

\section{Introduction}

According to the World Health Organization, an adolescent is an individual aged from 10 to 19 years. Adolescent is the time of transition from childhood to adulthood and characterized by significant physical, mental, and behavioral changes that may place their life at high risk $[1,2]$. Refugees are people including adolescents who have been forced to leave their homes to avoid the effects of armed conflict, generalized violence, violations of human rights, natural or human-made disasters and who have crossed an international border; they are highly vulnerable to different risky sexual behaviors [3].

Premarital sexual activities among adolescents are increasing from time to time worldwide particularly in developing countries like Ethiopia [4]. The premarital sexual practice among those adolescents particularly

\footnotetext{
*Correspondence: ghailay2015@gmail.com

1 Department of Public Health, College of Health Science, Aksum University, P.O. Box 298, Aksum, Ethiopia

Full list of author information is available at the end of the article
}

living in refugee camps is unprotected and predisposes for different sexual and reproductive health problems [5]. For instance, about $45 \%$ of all new HIV infections globally occurred among adolescents aged 15-24 years. In Africa, $60 \%$ of all new HIV infections occur in adolescents aged 15-19 years [6-8]. Each year, about 15 million adolescents aged 15-19 years gave birth; a large proportion of these pregnancies were unwanted, as many as 4 million experienced unsafe abortion, and up to 100 million were affected by STDs [9-11].

Studies in Ethiopia showed that $45 \%$ of the total birth occurs among adolescents aged 15-19 years of which $24.4 \%$ of them had an unwanted pregnancy and $89 \%$ with a history of abortion [12, 13]. The WHO report showed that sexual violence is frequently occurring among adolescents in developing countries [14]. About 54\% in Ethiopia and 48\% in Bangladesh adolescents aged 15-19 years had experienced sexual violence within the last 12 months respectively [14]. Another study conducted in Kenya showed that $40 \%$ sexually experienced adolescent girls and $65 \%$ of boys were having more than 
one sexual partner and only a few of them were using condoms [15].

Different studies conducted in developing countries revealed that substance use, peer influence, living arrangement, age, having pocket money, watching pornographic video and misconceptions on sexual risk behaviors were factors associated with premarital sexual practice and its complications [5, 16-19]. Although there were very limited studies, the risks of sexual and reproductive health problems are higher among adolescents living in the refugee camps than for adolescents in the general community [20]. Thus, the aim of this study was to assess the prevalence of premarital sexual practice and its associated factors among Adolescents living in refugee camps, in Tigray, northern Ethiopia.

\section{Main text \\ Methods \\ Study setting and period}

A community-based cross-sectional study was conducted in the refugee camps, located in North Tigray region, northern Ethiopia, at $1023 \mathrm{~km}$ from Addis Ababa. There are four refugee camps in Shire operation namely, Adi Harush, Shimelba, Mai-Aini, and Hitsats. According to the United Nation Higher Commissioner for Refugee (UNHCR) on 31 January 2018, there are a total of 44,683 refugees in the four identified camps of whom 13,800 are adolescents aged from 15-24 years. Each refugee camp has one health center and one elementary school. The participants of this study were unmarried adolescents 10-24 years old of the selected zones of the refugee camps, who had a refugee identification card. Those adolescents aged 10-24 years who were unable to communicate due to their physical and mental illnesses were excluded from the study. The study was done from April to May 2018.

\section{Sample size and sampling technique}

The sample size was calculated using a single population proportion formula considering the prevalence of premarital sexual practice among high school adolescents $21.1 \%$ [21], a margin of error $5 \%$ and adding $5 \%$ for nonresponse rate. The final sample size was 536 with a design effect of 2. Stratified sampling technique was used to include participants from the four refugee camps. After the proportional allocation to each refugee camp, simple random sampling was used to select individuals using the respective camp registry as a sampling frame.

\section{Data collection tools and procedure}

An anonymous, structured questionnaire was developed after reviewing relevant literatures that reviewed key variables as well as earlier studies on premarital sexual practice among adolescents $[4,7,13,16,20-22]$. The questionnaire and consent document was first developed in English and then translated into the local language (Tigrigna) and finally retranslated into English by another translator to check the consistency. The questionnaire had different parts which included socio-demographic, premarital sexual practice, risky behaviors, and related variables. Training was given for the data collectors and supervisors on how to conduct the interview and do the supervision.

Five percent of the questionnaire was pre-tested among adolescents in the nearby community for clarity and ascertain internal consistency. After analyzing the pretest result, necessary modifications were made accordingly before using the questionnaire in the actual survey. Data were collected by four clinical nurses under the supervision of two public health experts.

The primary outcome variable for the study was measured by the answers to the question: "Have you ever had sexual intercourse?" The adolescents were free to respond either "Yes" or "No". Those who responded "Yes" and were never married were regarded as having premarital sexual practice.

\section{Data processing and analysis procedures}

The coded data were entered into Epi-info Version 3.5.3 and then exported to SPSS Version 21 for analysis. Descriptive statistics were used to describe the continuous and categorical variables. Crude association between dependent and independent variables was assessed by bivariable logistic regression. Multivariable logistic regression analysis was carried out to control confounding variables. In the multivariable logistic regression analysis, a $p$ value $<0.05$ and the $95 \%$ CI were considered to determine the statistical significance; adjusted odds ratio (AOR) was used to determine the strength of association.

\section{Results}

\section{Socio-demographic characteristics of the participants}

A total of 536 adolescents participated in this study with a response rate of $100 \%$. Majority of them, $369(68.8 \%)$ were males. The age (mean $\pm \mathrm{SD})$ of the study participants was $17.4 \pm 2.71$ (15-24 years). Based on their living arrangements, $250(46.6 \%)$ of the adolescents were living either alone or with friends (Table 1).

\section{Experiences of premarital sexual practices}

The prevalence of premarital sexual practice was $47.6 \%$ [95\% CI $(43.3 \%, 51.9 \%)]$. Majority of the adolescents, $347(64.7 \%)$ had girl/boyfriends. Most of the adolescents $(53.7 \%)$ who have had premarital sex were in the age group of 14 to 19 years. One hundred sixty-seven 
Table 1 Socio-demographic characteristics of the study participants in Tigray, refugee camps, northern Ethiopia, $2018(N=536)$

\begin{tabular}{|c|c|c|}
\hline Variables & Frequency & Percent (\%) \\
\hline \multicolumn{3}{|l|}{ Sex } \\
\hline Male & 369 & 68.8 \\
\hline Female & 167 & 31.2 \\
\hline \multicolumn{3}{|l|}{ Age } \\
\hline$<14$ & 158 & 29.5 \\
\hline $14-19$ & 234 & 43.7 \\
\hline $20-24$ & 144 & 26.9 \\
\hline \multicolumn{3}{|l|}{ Living with arrangement } \\
\hline With father and mother & 131 & 24.4 \\
\hline Father only or mother only & 155 & 28.9 \\
\hline Relatives/friends & 109 & 20.3 \\
\hline Alone & 141 & 26.3 \\
\hline \multicolumn{3}{|l|}{ Family marital status } \\
\hline They live together & 215 & 40.1 \\
\hline Separated & 118 & 22.0 \\
\hline Divorced & 94 & 17.5 \\
\hline Widowed & 109 & 20.3 \\
\hline \multicolumn{3}{|l|}{ Previous residence } \\
\hline Urban & 199 & 37.1 \\
\hline Rural & 337 & 62.9 \\
\hline \multicolumn{3}{|l|}{ Religion } \\
\hline Orthodox & 309 & 57.6 \\
\hline Muslim & 116 & 21.6 \\
\hline Catholic & 90 & 16.8 \\
\hline Protestant & 21 & 3.9 \\
\hline \multicolumn{3}{|l|}{ Educational status } \\
\hline Unable to read and write & 119 & 22.2 \\
\hline Only read and write & 158 & 29.5 \\
\hline Primary school (grade 1-8) & 150 & 28.0 \\
\hline Secondary school (grade 9-12) & 80 & 14.9 \\
\hline College and above & 29 & 5.4 \\
\hline \multicolumn{3}{|l|}{ Ethnicity } \\
\hline Tigrigna speakers & 495 & 92.4 \\
\hline Other ${ }^{\mathrm{a}}$ & 41 & 7.6 \\
\hline \multicolumn{3}{|l|}{ Pocket money } \\
\hline Yes & 144 & 26.9 \\
\hline No & 392 & 73.1 \\
\hline
\end{tabular}

a Kunama, Amhara, Somali and Afar

(65.5\%) of them had sex with just acquaintance to their sexual partner. The reason for their first sex was the desire to practice sex in $103(40.4 \%)$ and peer pressure in 88 (34.5\%) of the respondents. No contraceptive method was used by 101 (39.6\%) of the adolescents who have had sex (Table 2).
Table 2 Distribution of experiences of adolescents on premarital sexual practices, in Tigray, refugee camps, northern Ethiopia May, 2018

\begin{tabular}{|c|c|c|}
\hline Variables & Frequency & Percent (\%) \\
\hline \multicolumn{3}{|l|}{ Have had ever sex $(n=536)$} \\
\hline No & 281 & 52.4 \\
\hline Yes & 255 & 47.6 \\
\hline \multicolumn{3}{|l|}{ Had boy/girl friend $(n=536)$} \\
\hline Yes & 347 & 64.7 \\
\hline No & 189 & 35.3 \\
\hline \multicolumn{3}{|l|}{ Age of first sex $(n=255)$} \\
\hline$<14$ & 92 & 36.1 \\
\hline $14-19$ & 137 & 53.7 \\
\hline $20-24$ & 26 & 10.2 \\
\hline \multicolumn{3}{|c|}{ Relationship to first sexual partner $(n=255)$} \\
\hline Acquaintances & 167 & 65.5 \\
\hline Friend & 88 & 34.5 \\
\hline \multicolumn{3}{|l|}{ Reason for first sex $(n=255)$} \\
\hline Fall in love & 34 & 13.3 \\
\hline Desire to practice sex & 103 & 40.4 \\
\hline To get money and other gifts & 30 & 11.8 \\
\hline Peer pressure & 88 & 34.5 \\
\hline \multicolumn{3}{|c|}{ Motivation for premarital sex $(n=255)$} \\
\hline Watching pornography & 79 & 31.0 \\
\hline Watching erotic films & 93 & 36.5 \\
\hline Being intoxicated/drunk & 67 & 26.3 \\
\hline I don't know & 16 & 6.3 \\
\hline \multicolumn{3}{|c|}{ Did you use any contraceptive methods during your last sex $(n=255)$} \\
\hline Yes & 154 & 60.4 \\
\hline No & 101 & 39.6 \\
\hline \multicolumn{3}{|c|}{ Reason for not using contraceptives } \\
\hline Trust partner & 44 & 26.0 \\
\hline Ashamed to ask partners & 6 & 3.6 \\
\hline Ashamed to buy & 64 & 37.9 \\
\hline Partner objected & 9 & 5.3 \\
\hline No sexual experience & 46 & 27.2 \\
\hline
\end{tabular}

\section{Risk behaviors of premarital sex}

Regarding substance use, about $226(42.2 \%)$ of the respondents had the experience of smoking any tobacco products. About 105 (19.6\%) of them had the experience of chewing chat. Regarding alcohol consumption, 339 (63.2\%) had the experience of drinking any type of alcohol and from those about 127 (48.7\%) of them said that they had sexual practice after drinking alcohol and only $29(22.8 \%)$ of them used condom during sexual practice after drinking alcohol (Additional file 1: Table S1). 


\section{Source of information and discussion about sexuality and reproductive health}

From the 536 study participants, 276 (51.5\%) of them responded that they have had information about sexuality and reproductive health issues and their major sources of information were health professionals 100 (36\%) followed by family/friends 78 (28.3\%) (Additional file 2: Table S2).

\section{Factors associated with premarital sexual practice}

Results of the multiple logistic regression model showed that age of $14-19$ years [AOR $=4.50,95 \% \mathrm{CI}(2.29-8.84)$ ] and 20-24 years $[\mathrm{AOR}=9.76, \mathrm{CI}(4.58-20.82)]$, primary education $[\mathrm{AOR}=6.93,95 \%$ CI $(3.08-15.57)]$, having monthly pocket money $[\mathrm{AOR}=4.14,95 \% \mathrm{CI}$
(2.31-7.41)], living arrangement \{living with their relatives/friends $[\mathrm{AOR}=5.24,95 \% \mathrm{CI}(2.28-12.05)]$ and living alone $[\mathrm{AOR}=5.72,95 \% \mathrm{CI}(2.69-12.19)]\}$, alcohol consumption $[\mathrm{AOR}=1.99,95 \% \mathrm{CI}(1.20-3.38)]$, and family marital status \{divorced [AOR $=5.11,95 \%$ CI $(2.42-$ $10.80)]$ or widowed $[\mathrm{AOR}=3.52,95 \%$ CI $(1.69-7.33)]\}$. were found to be significantly associated with premarital sexual practice (Table 3 ).

\section{Discussion}

This community-based cross-sectional study tried to assess the premarital sexual practice and its associated factors among adolescents who lived in the refugee camps in Tigray, northern Ethiopia. In this study, about

Table 3 Multivariate logistic regression on premarital sexual practice among adolescents in Tigray, refugee camps, northern Ethiopia, May, 2018

\begin{tabular}{|c|c|c|c|c|}
\hline \multirow[t]{3}{*}{ Variables } & \multicolumn{2}{|c|}{ Pre-marital sex } & \multirow[t]{3}{*}{$\operatorname{COR}(95 \%, \mathrm{Cl})$} & \multirow[t]{3}{*}{$\operatorname{AOR}(95 \%, \mathrm{Cl})$} \\
\hline & No & Yes & & \\
\hline & n (\%) & n (\%) & & \\
\hline \multicolumn{5}{|l|}{ Sex } \\
\hline Male & $218(59.1)$ & $151(40.9)$ & 1 & 1 \\
\hline Female & $63(37.7)$ & $104(62.3)$ & $2.38(1.64-3.47)$ & $1.83(0.94-3.56)$ \\
\hline \multicolumn{5}{|l|}{ Age } \\
\hline$<14$ & $96(60.8)$ & $62(39.2)$ & 1 & 1 \\
\hline $14-19$ & $121(51.7)$ & $113(48.3)$ & $1.45(.96-2.18)$ & $4.50(2.29-8.84)$ \\
\hline $20-24$ & $64(44.4)$ & $80(55.6)$ & $1.94(1.22-3.06)$ & $9.76(4.58-20.82)$ \\
\hline \multicolumn{5}{|l|}{ Living condition } \\
\hline With father and mother & $97(74.0)$ & $34(26.0)$ & 1 & 1 \\
\hline Father or mother only & $91(58.7)$ & $64(41.3)$ & $2.00(1.21-3.32)$ & $1.46(0.78-2.71)$ \\
\hline Relatives/friends & $41(37.6)$ & $68(62.4)$ & $4.73(2.73-8.20)$ & $5.24(2.28-12.05)$ \\
\hline Alone & $52(36.9)$ & $89(63.1)$ & $4.88(2.91-8.21)$ & $5.72(2.69-12.19)$ \\
\hline \multicolumn{5}{|l|}{ Education status } \\
\hline Unable to read and write & $75(63.0)$ & $44(37.0)$ & 1 & 1 \\
\hline Only read and write & $102(64.6)$ & $56(35.4)$ & $0.94(0.57-1.54)$ & $0.62(0.32-1.20)$ \\
\hline Primary school & $51(34.0)$ & $99(66.0)$ & $3.31(2.00-5.47)$ & $6.93(3.08-15.57)$ \\
\hline Secondary school & $40(50.0)$ & $40(50.0)$ & $1.71(0.96-3.03)$ & $2.17(1.00-4.69)$ \\
\hline College and above & $13(44.8)$ & $16(55.2)$ & $2.10(.92-4.77)$ & $4.33(1.44-13.02)$ \\
\hline \multicolumn{5}{|l|}{ Family marital status } \\
\hline They live together & $145(67.4)$ & $70(32.6)$ & 1 & 1 \\
\hline Separated & $80(67.8)$ & $38(32.2)$ & $0.98(0.61-1.59)$ & $0.46(0.21-1.01)$ \\
\hline Divorced & $20(21.3)$ & $74(78.7)$ & $7.66(4.33-13.56)$ & $5.11(2.42-10.80)$ \\
\hline Widowed & $36(33.0)$ & $73(67.0)$ & $4.20(2.57-6.86)$ & $3.52(1.69-7.33)$ \\
\hline \multicolumn{5}{|l|}{ Pocket money } \\
\hline No & $234(59.7)$ & $158(40.3)$ & 1 & 1 \\
\hline Yes & 47 (32.6) & $97(67.4)$ & $3.06(2.04-4.57)$ & $4.14(2.31-7.41)$ \\
\hline \multicolumn{5}{|l|}{ Ever consumption alcohol } \\
\hline No & $134(68.0)$ & $63(32.0)$ & 1 & 1 \\
\hline Yes & $147(43.4)$ & $192(56.6)$ & $2.78(1.92-4.02)$ & $1.99(1.20-3.38)$ \\
\hline
\end{tabular}

Odds ratio and $\mathrm{Cl}$ written in italics indicates statistical significance at $\mathrm{p}$ value $<0.05$ 
half of the adolescents (47.6\%) in the refugee camps have had premarital sexual practice. Even though there are limited studies about premarital sexual practice particularly among refugee adolescents at the national and local level, the finding of this study is higher than the previous study conducted in Ethiopia among high school adolescent which was 33\% [22]. The higher prevalence among refugee adolescents might be due to their difficult living conditions; they did not have permanent residence and they might not be benefited from the sustainable health educations programs about sexual reproductive problems. On the other hand, the finding is similar with another survey conducted in Ethiopia among youth which was almost $50 \%$ [23]. This result may imply that there is high probability of youths in refugee who can easily engage in sexual practice.

Age of respondents was associated with the premarital sexual practice; those adolescents whose age was between 14 and 19 years were 4.5 times more likely to start premarital sex compared to adolescents $<14$ years of age $[\mathrm{AOR}=4.50,95 \% \mathrm{CI}(2.29-8.84)]$ and those adolescents whose age was between 20 and 24 years were 9.76 times more likely to start premarital sex compared to adolescents $<14$ years of age $[\mathrm{AOR}=9.76$, CI $(4.58-20.82)]$. This finding is in agreement with previous studies conducted in Ethiopia among adolescents [24, 25].

Living arrangement of the respondent was significantly associated with premarital sexual practice. Those adolescents who were living with their relatives/friends were 5.24 times more likely to start premarital sex compared to adolescents living with their mother and father $[\mathrm{AOR}=5.24,95 \% \mathrm{CI}(2.28-12.05)]$ and those adolescents who were living alone were 5.72 times more likely to start premarital sex compared to adolescents living with their mother and father $[\mathrm{AOR}=5.72,95 \%$ CI $(2.69-12.19)]$. Previous researches had indicated that parental involvement affects adolescent behavior primarily through monitoring. Parents, who spend more time supervising their children have children who engage in fewer risky and premarital sexual behaviors [26, 27].

Educational status of the respondents was also associated with premarital sexual practice; those adolescents who attended primary school were 6.93 times more likely to start premarital sex compared to adolescents who were unable to read and write $[\mathrm{AOR}=6.93,95 \%$ CI (3.08-15.57)] and being college and above holder was 4.33 times more likely to start premarital sex compared to adolescents who were unable to read and write $[\mathrm{AOR}=4.33, \mathrm{CI}(1.44-13.02)]$. The current finding is not consistent with previous studies conducted elsewhere $[12,21,28]$.

This study had also identified the likelihood of premarital sexual practice was higher among adolescents whose parents were either divorced or widowed. Moreover, respondents having pocket money were 4.14 times more likely to start premarital sex compared to adolescents who did not have pocket money $[\mathrm{AOR}=4.14,95 \%$ CI (2.31-7.41)]. Other studies identified that a number of social factors exerted a large measure of influence on the attitude of refuge adolescents towards sexual practice $[28,29]$. Especially adolescents living in the refugee camp with poor monitoring around the refuge environment and refugee peers provide adolescents the opportunity to expose them to unhealthy behavior contributing to poor decision-making including substance use [30]. Regarding substance use, respondents who consumed alcohol were 1.99 times more likely to engage on premarital sexual practice than non-users $[A O R=1.99,95 \%$ CI (1.20-3.38)] which is in agreement with other studies $[28,31,32]$. In the general, the prevalence of premarital sexual practice was high in the study group. Age, living with friends/alone, being in primary/secondary schools or college and above, getting pocket money, having divorced/widowed parents and alcohol consumption were predictors of premarital sexual practice. Considering the high prevalence of early sexual intention, there should be sustainable community-based health education to reduce the premarital sexual practice among refugee adolescents.

\section{Limitation of the study}

As it was a cross sectional study, causality may not be established and owing to the sensitive nature of the outcome variable, the current reported prevalence may under estimate the real prevalence on the ground and also this study was conducted within few refugee camps in Tigray regional state on limited numbers of adolescents who were living at the selected refugee camps which means the findings may not be generalizable to the overall Ethiopian adolescents living at the selected camps or other refugee camps.

\section{Additional files}

Additional file 1: Table S1. Distribution of adolescents by risk behaviors
in Tigray, refugee camps, northern Ethiopia, May, 2018 .

Additional file 2: Table S2. Distribution of adolescents by source of information about sexuality and reproductive health issues, in Tigray, refugee camps, northern Ethiopia, May, 2018.

\section{Abbreviations}

AIDS: acquired immunodeficiency syndrome; DHS: Demographic and Health Survey; HIV: human immunodeficiency virus; NGO: Non-Governmental Organization; $\mathrm{RH}$ : reproductive health; STD: sexually transmitted disease; STIs: sexually transmitted infections; USA: United State of America; WHO: World Health Organization. 


\begin{abstract}
Acknowledgements
Our heartfelt gratitude goes to the administrators of the refugee camps, data collectors, supervisors, study participants and guardians of the study participants.
\end{abstract}

\section{Authors' contributions}

HG; wrote the proposal, participated in data collection, analyzed the data and drafted the paper. TB and MT; approved the proposal with great revisions, participated in data analysis and revised subsequent drafts of the paper. GH, TW, ZW and GG participated in the data analysis and drafted the paper. All authors read and approved the final manuscript.

\section{Funding}

This work was funded by Aksum University College of health science. The funder financed the process of data collection only.

\section{Availability of data and materials}

The datasets on which conclusion was made is available in the form of Microsoft Excel. It is available on reasonable request.

\section{Ethics approval and consent to participate}

Ethical approval and clearance were obtained from Aksum University College of Health Sciences research ethics review committee. Written permission letter was obtained from the respective refugee camp administrators. Written consent was obtained after the potential participants and their parents/guardians (for those under 18 years) were informed of the study's objectives and reading the information sheet. Only adolescents/parents/guardians who gave consent to participate were included in the study. All participants were also informed that they could withhold or withdraw from participation at any time without any negative consequences. Confidentiality and privacy of the study were maintained during data collection, analysis, and reporting by making the questionnaire anonymous.

\section{Consent for publication}

Not applicable.

\section{Competing interests}

This is to confirm that all authors have reviewed the submitted research article and approved the paper for submission. All authors also declare that they have no financial or non-financial competing interests. This manuscript has not been published elsewhere and is not under submission elsewhere.

\section{Author details}

1 Department of Public Health, College of Health Science, Aksum University, P.O. Box 298, Aksum, Ethiopia. ${ }^{2}$ School of Medicine, College of Health Science, Aksum University, Aksum, Ethiopia. ${ }^{3}$ Department of Medical Laboratory Sciences, College of Health Science, Aksum University, Aksum, Ethiopia. ${ }^{4}$ Administration for Refugee and Returnee Affairs Adiharsh Eritrean Refugee Camps Health and Neutrino Coordinator, Adiharsh, Addis Ababa, Ethiopia.

Received: 24 May 2019 Accepted: 9 July 2019

Published online: 15 July 2019

\section{References}

1. Regnerus M, Uecker J. Premarital sex in America: how young Americans meet, mate, and think about marrying. Oxford: Oxford University Press; 2011.

2. Wilson CM, Wright PF, Safrit JT, Rudy B. Epidemiology of HIV infection and risk in adolescents and youth. J Acquir Immune Defic Syndr. 2010;54(1):5.

3. UNHCR. A year of crises: UNHCR global trends 2011. Geneva: UNHCR; 2011. p. 2011.

4. Lynne Cooper M. Risky sexual behaviour and associated factors among college adolescents and youth: evaluating the evidence. J Stud Alcohol. 2012;14(14):101-17.

5. McClure CA, Gray G, Rybczyk GK, Wright PF. Challenges to conducting HIV preventative vaccine trials with adolescents. JAIDS J Acquir Immune Defic Syndr. 2004;36(2):726-33.
6. Jejeebhoy SJ, Zavier AF, Santhya KG. Meeting the commitments of the ICPD programme of action to young people. Reprod Health Matt. 2013;21(41):18-30

7. Dorothy S. Access to sexual and reproductive health for young people: bridging the disconnect between rights and reality. Int I Gynecol Obstetr. 2009;06(2):132-6.

8. WHO, GTZ, GmbH. Sexually transmitted infections among adolescents: the need for adequate health services. Geneva: WHO; 2005.

9. Williamson LM, Parkes A, Wight D, Petticrew M, Hart GJ. Limits to modern contraceptive use among young women in developing countries: a systematic review of qualitative research. Reprod Health. 2009;6(1):3.

10. UNFP. State of world population making 1 billion counts. Investing in adolescent health and rights. New York: UNFPA; 2003.

11. De BruynMa P. Adolescent's unwanted pregnancy and abortion. Policies, counseling and clinical care. New Yok: IPAS; 2004.

12. UNFPA. People and possibilities in a world of 7 billion, state of world population. New York: UNFPA; 2011.

13. Mulugeta Y, Berhane Y. Factors associated with pre-marital sexual debut among unmarried high school female adolecents in Bahir Dar town, Ethiopia. Reprod Health J. 2014;11:40.

14. Akwara PA, Madise NJ. Perception of risk of HIV/AIDS and sexual behavior in Kenya. J Biosoc Sci. 2008;35(3):385-411.

15. World Health Organization. WHO multi-country study on women's health and domestic violence against women: summary report of initial results on prevalence, health outcomes and women's responses. Geneva: WHO; 2005.

16. Adeoye A, Omolayo O, Aliu B. Prevalence of premarital sex and factors influencing it among adolecents in a private tertiary institution in Nigeria. Int J Psychol Counsel. 2012;4:6-9.

17. Amsale C, Yemane B. Peer pressure is the prime driver of risky sexual behaviors among school adolescents in Addis Ababa. Ethiopia World $」$ AIDS. 2012;2:159-64.

18. Deribew A, Tesfaye M, Hailmichael Y, Apers L, Abebe G, Duchateau L, Colebunders R. Common mental disorders in TB/HIV co-infected patients in Ethiopia. BMC Infect Dis. 2010;10(1):201.

19. Hong Y, Li L, Yongyi B, Xunyu X, Shiyue L, Jay E. Family and peer influences on sexual behavior among female college adolecents in Wuhan. Chin Women Health. 2010;50(8):767-82.

20. Spiegel PB, Schilperoord M, Dahab M. High-risk sex and displacement among refugees and surrounding populations in 10 countries: the need for integrating interventions. Aids. 2014;28(5):761-71.

21. Kassa GM, Woldemariam EB, Moges NA. Prevalence of premarital sexual practice and associated factors among Alamata high school and preparatory school adolescents, northern Ethiopia. Glob J Med Res. 2014;12:314

22. Assefa S, Dessalegn W. Premarital sexual practice among school adolescents in Nekemte Town. East Wollega Ethiop J Health Dev. 2008;22(2):169.

23. UNICEF \& African Child Policy Forum. What children and youth think a statistical presentation of opinions and perceptions of children and youth in Ethiopia; 2006

24. Westercamp N, Moses S, Agot K, Ndinya-Achola JO, Parker C, Amolloh KO, Bailey RC. Spatial distribution and cluster analysis of sexual risk behaviors reported by young men in Kisumu, Kenya. Int J Health Geogr. 2010;9(1):24.

25. Khan M, Brown L. HIV-related sexual behavior in urban, rural and border areas of Burkina Faso. AIDS Behav. 2006;10(5):607-17.

26. Shiferaw $\mathrm{S}$. The effect of living arrangements and parental attachment on sexual risk behaviors and psychosocial problems of adolescents in Dessie preparatory school. Ethiopia: Addis Ababa; 2004.

27. Astrat A. Assessment of sexual risk behaviors of in-school youth: effect of living arrangement of students. Amhara Regional: West Gojam zone; 2009.

28. Russell TV, Do AN. Sexual risk behaviors for HIV/AIDS in Chuuk State, Micronesia: the case for HIV prevention in vulnerable remote populations. PLOS ONE. 2007:2(12):e1283.

29. Yan AF, Chiu YW. STD-/HIV-related sexual risk behaviors and substance use among US rural adolescents. J Natl Med Assoc. 2007:99(12):1386.

30. Kliewer W, Murrelle L. Risk and protective factors for adolescent substance use: findings from a study in selected Central American countries. J Adolesc Health. 2007:40:448-55. 
31. Malhotra S. Impact of the sexual revolution: consequences of risky sexual behaviors. J Am Phys Surg. 2008;13(3):88.

32. Prinstein MJ, La Greca AM. Childhood peer rejection and aggression as predictors of adolescent girls' externalizing and health risk behaviors: a 6-year longitudinal study. J Consult Clin Psychol. 2004;72(1):103.

\section{Publisher's Note}

Springer Nature remains neutral with regard to jurisdictional claims in published maps and institutional affiliations.
Ready to submit your research? Choose BMC and benefit from:

- fast, convenient online submission

- thorough peer review by experienced researchers in your field

- rapid publication on acceptance

- support for research data, including large and complex data types

- gold Open Access which fosters wider collaboration and increased citations

- maximum visibility for your research: over $100 \mathrm{M}$ website views per year

At BMC, research is always in progress.

Learn more biomedcentral.com/submissions 